\title{
Pengaruh Metode Pembelajaran Kulponsi Terhadap Prestasi Belajar Siswa Kelas IV SDIT Al-Istiqomah NW
}

\author{
${ }^{1}$ Rahman, ${ }^{2}$ Nurlaila, ${ }^{3}$ Raden Sumiadi \\ 1,2,3 STKIP Hamzar
}

\begin{tabular}{l}
\hline Article Info \\
Article history: \\
Article Accepted: 29 Juni 2021 \\
Publication : 15 Juli 2021
\end{tabular}

Keywords:

Metode kulponsi, prestasi belajar

Corresponding Author:

\begin{abstract}
Abstrak
Penelitian ini bertujuan untuk melihat pengaruh metode pembelajaran kulponsi terhadap prestasi belajar siswa kelas IV SDIT Al-Istiqomah NW. Penelitian ini di desain dengan quasi eksperimen yang terdiri dari kelas eksperimen dan kontrol. Instrumen tes yang digunakan dalam penelitian ini dianalisis nilai validitas dan realibilitasnya. Dan diperoleh hasil bahwa butir soal valid dan reliabel. Uji hipotesis untuk mengetahui pengaruh metode kulponsi dianalisis dengan menggunakan statistik inferensial dengan rumus korelasi produk moment. Hasil penelitian menunjukkan bahwa terdapat pengaruh signifikan penggunaan pengaruh metode kulponsi terhadap prestasi belajar siswa kelas IV SDIT Al-istiqomah NW.
\end{abstract}

This is an open access article under the Lisensi Creative Commons AtribusiBerbagiSerupa 4.0 Internasional (c) (1) (-)

\section{Rahman \\ STKIP Hamzar}

\section{PENDAHULUAN}

Undang-Undang Pendidikan Nomor 20 Tahun 2003 tentang sistem pendidikan nasional menyatakan bahwa pendidikan adalah usaha sadar dan terencana untuk mewujudkan suasana belajar dan proses pembelajaran agar siswa secara aktif mengembangkan potensi diri, kepribadian, kecerdasan, akhlak mulia serta keterampilan yang diperlukan dirinya, masyarakat, bangsa dan negara.

Untuk mewujudkan suasana belajar yang baik dibutuhkan kesiapan guru dalam mengelola pembelajaran di kelas. Guru sebagai ujung tombak pendidikan memiliki peran penting dalam menentukan keberhasilan pendidikan. Oleh karena itu, upaya peningkatan kualitas pendidikan harus dimulai dari pembenahan kompetensi guru, salah satunya kompetensi pedagogik yaitu kemampuan guru dalam merancang strategi pembelajaran yang sesuai dengan tujuan yang akan dicapai.

Guru perlu memiliki kemampuan merancang dan mengimplementasikan berbagai strategi pembelajaran yang dianggap cocok dengan minat dan bakat serta sesuai dengan tarap perkembangan siswa termasuk didalamnya memanfaatkan berbagai sumber dan media pembelajaran untuk menjamin efektivitas pembelajaran (Sanjaya, 2007).

Peningkatan dan perabaikan mutu pendidikan hendaknya dimulai dari perabaikan kualitas guru dalam mengelola pembelajaran sehingga setiap guru mampu menginovasikan metode yang dapat menstimulus siswa dalam belajar. Salah satunya adalah penggunaan metode kulponsi. Metode pembelajaran kulsponsi merupakan metode yang dalam prakteknya tidak digunakan sendiri-sendiri, tetapi merupakan kombinasi dari beberapa metode mengajar, dimana kombinasi metode mengajar tersebut seperti; ceramah, tanya jawab dan tugas; ceramah, diskusi dan tugas; ceramah, demonstrasi dan eksperimen; cermah, responsi dan tugas; ceramah, pemecahan 
masalah dan tugas; ceramah, demonstrasi dan latihan (Djamarah dan Zain, 2002). Kelebihan dari metode kulsponsi adalah guru dapat melaksanakan pembelajan dengan lebih mudah, walaupun jumlah siswa cukup banyak, karena metode kulsponsi merupakan penyatuan dari metodemetode yang lain, sehingga pembelajaran dapat diatur menjadi lebih sederhana dan tidak memerlukan setting yang beragam.

Berdasarkan hasil observasi terhadap pelaksanaan pembelajaran IPS siswa kelas IV SDIT Al-Istiqomah NW Mamben Baru, terungkap bahwa guru cenderung melaksanakan pembelajaran konvensional yang mengakibatkan monotonnya pembelajaran, siswa hanya mendengarkan penjelasan materi pelajaran dari guru, sehingga timbul persepsi dikalangan siswa bahwa pembelajaran IPS itu membosankan dan kurang menarik. Perhatian siswa selama proses pembelajaran berlangsung kurang begitu terpusat yang mengakibatkan sebagian materi yang disampaikan tidak terserap oleh siswa. Hal ini dapat dilihat dari hasil nilai ulangan harian siswa yang berjumlah 38 siswa, dari jumlah tersebut hanya 16 siswa atau 42,10\% yang nilainya mencapai kriteria ketuntasan minimal (KKM) yang telah ditentukan di SDIT Al-Istiqomah NW Mamben Baru yaitu $\geq 70$. Sedangkan siswa yang tidak tuntas ada 22 siswa atau 57,89\%. Ini yang terjadi pada siswa kelas IV SDIT Al-Istiqomah NW Mamben Baru, masih mengalami kesulitan dalam proses pembelajaran IPS yang terlihat pada hasil belajarnya di kelas dengan perolehan rata-rata nilai kurang dari 70 atau 57,89\%. Perolehan tersebut belum mencapai KKM yang ditetapkan disekolah yaitu 70 .

Sehubungan dengan uraian tersebut di atas, maka dipandang perlu melakukan penelitian dengan judul pengaruh metode pembelajaran kulsponsi terhadap prestasi belajar IPS siswa kelas IV SDIT Al-Istiqomah NW Mamben Baru Tahun Pelajaran 2020/2021”.

\section{METODE PENELITIAN}

Penelitian ini merupakan jenis penelitian kuantitatif dengan desain quasi eksperimen. Bentuk desain penelitian yaitu The posttest control group desain:

$$
\begin{array}{lll}
\mathrm{E} & \mathrm{x} & \mathrm{O}_{1} \\
\mathrm{~K} & & \mathrm{O}_{2}
\end{array}
$$

(Dantes, 2012)

Keterangan :

$$
\begin{array}{cl}
\mathrm{E} & : \text { Eksperimen } \\
\mathrm{K} & : \text { Kontrol } \\
\mathrm{X} & : \text { Kelas dengan perlakuan metode pembelajaran kulsponsi } \\
\mathrm{O}_{1} & : \text { Posttest pada kelompok eksperimen } \\
\mathrm{O}_{2} & : \text { Posttest pada kelompok kontrol }
\end{array}
$$

Instrumen dalam penelitian ini berupa tes hasil belajar dalam bentuk soal pilihan ganda. Sebelum digunakan instrumen diuji validitas, realibilitas dan tingkat kesukarannya.

1. Validitas Butir Tes

Uji validitas butir soal bertujuan untuk mengetahui kebenaran jawaban butis soal yang diberikan oleh siswa dengan menggunakan rumus sebagai berikut :

$$
\mathrm{r}_{x y}=\frac{N \Sigma \mathrm{XY}-(\Sigma \mathrm{X})(\Sigma \mathrm{Y})}{\sqrt{\left\{\left(N \Sigma \mathrm{X}^{2}-(\Sigma X)^{2}\right)\left(N \Sigma \mathrm{Y}^{2}-(\Sigma Y)^{2}\right)\right\}}} \text { (Arikunto, 2010:213) }
$$

2. Reliabilitas Tes

Uji reliabilitas tes digunakan untuk mengetahui reliabilitas instrumen dengan menggunakan rumus Alpha sebagai berikut:

$$
\mathrm{r}_{11}=\left(\frac{k}{\mathrm{k}-1}\right)\left(1-\frac{\Sigma \sigma_{b}^{2}}{\sigma_{\mathrm{t}}{ }^{2}}\right)
$$

3. Uji hipotesis digunakan rumus korelasi Product moment

$$
\mathrm{r}_{\mathrm{xy}}=\frac{\Sigma \mathrm{XY}}{\sqrt{\left(\Sigma \mathrm{X}^{2}\right)\left(\Sigma \mathrm{Y}^{2}\right)}}
$$


(Arikunto, 2010:213).

Keterangan:

$r_{x y} \quad:$ Koefisien korelasi

$\sum X Y \quad$ : Jumlah hasil kali skor $\mathrm{X}$ dengan skor Y yang berpasangan

$\sum X^{2}$ : Jumlah skor yang dikuadratkan dalam sebaran $\mathrm{X}$

$\sum \mathrm{Y}^{2} \quad$ : Jumlah skor yang dikuadratkan dalam sebaran $\mathrm{Y}$

\section{HASIL DAN PEMBAHASAN}

\subsection{Hasil Penelitian}

Tabel 1.1 Nilai Rata-rata Prestasi Belajar Kelas Eksperimen Dan Kelas Kontrol.

\begin{tabular}{|c|l|c|c|}
\hline \multirow{2}{*}{ No } & \multirow{2}{*}{ Parameter } & \multicolumn{2}{|c|}{ Posttest } \\
\cline { 3 - 4 } & & Eksperimen & Kontrol \\
\hline 1 & Nilai Tertinggi & 100 & 95 \\
\hline 2 & Nilai Terendah & 75 & 70 \\
\hline 3 & Jumlah & 1739 & 1516 \\
\hline 4 & Rata-rata & 91,52 & 79,79 \\
\hline
\end{tabular}

Tabel 1.2 Sebaran Nilai Posttest Kelas Eksperimen.

\begin{tabular}{|c|c|c|c|}
\hline No & Interval & Frekuensi & Persen \\
\hline 1 & $75-80$ & 2 & 10,53 \\
\hline 2 & $81-86$ & 3 & 15,79 \\
\hline 3 & $87-92$ & 4 & 21,06 \\
\hline 4 & $93-98$ & 8 & 42,1 \\
\hline 5 & $99-100$ & 2 & 10,53 \\
\hline \multicolumn{2}{|c|}{ Jumlah } & 19 & - \\
\hline
\end{tabular}

Tabel 1.3 Sebaran Nilai Posttest Kelas kontrol.

\begin{tabular}{|c|c|c|c|}
\hline No & Interval & Frekuensi & Persen \\
\hline 1 & $70-75$ & 6 & 31,58 \\
\hline 2 & $76-81$ & 7 & 36,84 \\
\hline 3 & $82-87$ & 3 & 15,79 \\
\hline 4 & $88-93$ & 2 & 10,53 \\
\hline 5 & $94-100$ & 1 & 5,27 \\
\hline \multicolumn{2}{|c|}{ Jumlah } & 19 & - \\
\hline
\end{tabular}

Tabel 1.4. Rekapitulasi Data Posttest Pada Kedua Kelas

\begin{tabular}{|c|c|c|}
\hline Keterangan & $\begin{array}{c}\text { Kelas } \\
\text { Eksperimen }\end{array}$ & $\begin{array}{c}\text { Kelas } \\
\text { Kontrol }\end{array}$ \\
\hline Nilai Maksimal & 100 & 95 \\
\hline Nilai Minimal & 75 & 70 \\
\hline Range $(\mathrm{R})$ & 25 & 25 \\
\hline Mean $(X)$ & 91,52 & 79,79 \\
\hline Standar Deviasi & 6,66 & 6,50 \\
\hline
\end{tabular}

Tabel 1.5 Sebaran Nilai Posttes Kelas Eksperimen 


\begin{tabular}{|c|c|c|c|}
\hline No & Interval & Frekuensi & Persen \\
\hline 1 & $75-80$ & 2 & 10,53 \\
\hline 2 & $81-86$ & 3 & 15,79 \\
\hline 3 & $87-92$ & 4 & 21,06 \\
\hline 4 & $93-98$ & 8 & 42,1 \\
\hline 5 & $99-100$ & 2 & 10,53 \\
\hline \multicolumn{2}{|c|}{ Jumlah } & 19 & - \\
\hline
\end{tabular}

Tabel 1.6 Sebaran Nilai Posttes Kelas kontrol

\begin{tabular}{|c|c|c|c|}
\hline No & Interval & Frekuensi & Persen \\
\hline 1 & $70-75$ & 6 & 31,58 \\
\hline 2 & $76-81$ & 7 & 36,84 \\
\hline 3 & $82-87$ & 3 & 15,79 \\
\hline 4 & $88-93$ & 2 & 10,53 \\
\hline 5 & $94-100$ & 1 & 5,27 \\
\hline \multicolumn{2}{|c|}{ Jumlah } & 19 & - \\
\hline
\end{tabular}

Tabel 2.4. Rekapitulasi Data Nilai Posttest Pada Kedua Kelas

\begin{tabular}{|c|c|c|}
\hline Keterangan & Kelas Eksperimen & $\begin{array}{c}\text { Kelas } \\
\text { Kontrol }\end{array}$ \\
\hline Nilai Maksimal & 100 & 95 \\
\hline Nilai Minimal & 75 & 70 \\
\hline Range (R) & 25 & 25 \\
\hline Mean (X) & 91,52 & 79,79 \\
\hline Standar Deviasi & 6,66 & 6,50 \\
\hline
\end{tabular}

\subsection{Pembahasan}

Data merupakan elemen terpenting yang harus didapatkan dalam penelitian. Oleh karena itu keabsahan instrumen pengumpul data sangat penting untuk diperhatikan. Dalam penelitian ini, keabsahan instrumen pengumpul data dalam bentuk tes soal dapat dideskripsikan sebagai berikut: Data validitas, reliabilitas, tingkat kesukaran. Validitas Tes, Terdapat 30 soal yang valid (lampiran 4). Dimana $r_{\text {hitung }}>r_{\text {tabel }}$ yaitu 0,581 $>0,349$ (lampiran 9). Reliabilitas Tes, diketahui $r_{\text {hitung }}>r_{\text {tabel }}$ yaitu $0,631>0,349$. Dengan demikian dapat disimpulkan bahwa tes yang digunakan adalah tes yang reliabel. Tingkat Kesukaran Tes, diperoleh kriteria soal sukar berjumlah $5 \%$, kriteria soal sedang berjumlah $30 \%$, dan kriteria soal mudah berjumlah $65 \%$

Berdasarkan pengujian hipotesis yang dilakukan, maka terdapat pengaruh metode pembelalajaran kulsponsi terhadap prestasi belajar siswa kelas IV SDIT Al-Istiqomah NW Mamben Baru dengan melihat hasil perhitungan diperoleh harga $t_{\text {hitung }}$ adalah 18,08 dan $t_{\text {tabel }}$ dengan derajat kebebasan : 36 pada taraf signifikan 5\% adalah 1,89. Maka $t_{\text {hitung }}>t_{\text {tabel }}$ yaitu $18,08>1,89$. Berangkat dari kenyataan itu, maka hasil penelitian ini dinyatakan signifikan yang berarti hipotesis nol $\left(\mathrm{H}_{\mathrm{o}}\right)$ ditolak, dengan demikian hipotesis alternatif $\left(\mathrm{H}_{\mathrm{a}}\right)$ yang diajukan diterima.

Mengingat hipotesis nol ditolak dan hipotesis alternatif diterima, menunjukkan bahwa metode pembelajaran kulsponsi berpengaruh secara signifikan terhadap prestasi belajar siswa pada mata pelajaran IPS kelas IV SDIT Al-Istiqomah NW. begitu juga dengan nilai rata-rata yang diperoleh pada kelas eksperimen setelah perlakuan yaitu 91,5. Nilai tersebut berada pada katagori tinggi. Sehingga dapat disimpulkan bahwa terdapat pengaruh metode 
pembelajaran kulsponsi terhadap prestasi belajar siswa pada mata pelajaran IPS kelas IV SDIT Al-Istiqomah NW Mamben Baru tahun pelajaran 2020/2021 tergolong tinggi.

\section{KESIMPULAN}

Berdasarkan hasil penelitian dan pembahasan dapat disimpulkan bahwa : terdapat pengaruh metode pembelajaran kulsponsi terhadap prestasi belajar IPS siswa kelas IV di SDIT Al-Istiqomah NW Mamben Baru tahun pelajaran 2020/2021. Hal ini dapat dilihat hasil uji hipotesis yaitu $\mathbf{T}_{\text {hitung }}$ lebih besar dari $\mathbf{T}_{\text {tabel }}(18,08>1,89)$ pada taraf signifikan $5 \%$, dengan demikian hipotesis alternatif $\left(\mathrm{H}_{\mathrm{a}}\right)$ diterima dan hipotesis nol $\left(\mathrm{H}_{0}\right)$ ditolak. Dan berdasarkan hasil prestasi belajar siswa pada metode pembelajaran kulsponsi lebih tinggi nilainya bila dibandingkan dengan metode konvensional, ini dapat dilihat pada nilai rata-rata dari masingmasing kelas, dimana pada kelas eksperimen memiliki nilai sebesar 91,52 dan kelas kontrol sebesar 79,79. Dengan demikian, proses pembelajaran yang menggunakan metode pembelajaran kulsponsi memiliki pengaruh yang signifikan terhadap prestasi belajar siswa.

\section{DAFTAR PUSTAKA}

Djamarah, B. 1994. Prestasi Belajar dan Kompetensi Guru. Surabaya : Usaha Nasional.

Djamarah, B dan Zain, A. 2002. Strategi Belajar Mengajar. Jakarta : Rineka Cipta.

Hamalik, 2009. Proses Belajar Mengajar. Bandung: PT. Bumi Aksara.

Hardani, dkk., 2020. Metode Penelitian Kualitatif Dan Kuantitatif. Yogyakarta: Pustaka Ilmu Group.

Roestiyah, NK., 2001. Strategi Belajar Mengajar. Jakarta: Rineka Cipta.

Utomo, T dan Ruitjer, K., 1991. Peningkatan dan Pengembangan Pendidikan. Jakarta: Gramedia.

Sanjaya, W., 2007. Strategi Pembelajaran Berorientasi Standar Proses Pendidikan. Jakarta: Kencana.

., 2014. Strategi Pembelajaran Berorientasi Standar Proses Pendidikan. Jakarta: Fajar Interpratama Mandiri.

Sugiyono, M., 2010. Metode Penelitian Administrasi dilengkapi Metode $R \& D$ Bandung: Alfabeta

Susanto. A., 2014. Pengembangan Pembelajaran IPS di Sekolah Dasar. Jakarta: Kencana. 